\title{
Occupational asthma in a pharmaceutical worker exposed to penicillamine
}

\author{
FRANÇOISE LAGIER, ANDRÉ CARTIER, JERRY DOLOVICH, JEAN-LUC MALO \\ From the Department of Chest Medicine, Hôpital du Sacré-Coeur, Montreal, and the Department of Pediatrics, \\ McMaster University, Hamilton, Canada
}

ABSTRACT A case of occupational asthma due to penicillamine is reported.

Many drugs have been reported as causing occupational asthma. ${ }^{12}$ Penicillamine $\left(\mathrm{C}\left(\mathrm{CH}_{3}\right)_{2}-\mathrm{SH}-\mathrm{CHCOOH}-\mathrm{NH}_{2}\right)$ is documented here as having caused occupational asthma in a pharmaceutical company worker.

\section{Case report}

A 32 year old man had worked for 14 years as an operator in a pharmaceutical company where he was exposed to different products, including penicillamine and guar gum. Seven years after starting work he noticed sneezing, dyspnoea, and wheezing on exposure to penicillamine and guar gum. These symptoms appeared immediately after exposure and persisted during the evening. The patient also reported symptoms of perennial rhinitis. Over the past 10 years exposure to cats had caused rhinitis symptoms and asthma. Occupational asthma due to guar gum had previously been confirmed in this patient and in other workers of a carpet company (personal observation). Skinprick tests showed a positive immediate reaction to cat dander and Dermatophagoides farinae extracts. Skinprick responses to penicillamine and to Penkit (benzylpenicilloyl polylisine and Minor Determinant Mixture, Stallergènes, Fresne, France), diluted in concentrations of $0.01,0.1$, and $1 \mathrm{mg} / \mathrm{ml}$, were negative. Peak expiratory flow rates were measured for four weeks both at work and at weekends when he was away from work. Daily changes in peak flow of over $20 \%$ were documented on two occasions, once after exposure to guar gum and the other time after exposure to a cat. During this period, however, the patient was not exposed to penicillamine. Baseline results for FEV , and forced vital capacity (FVC) were 3.23 and 4.77 litres with a $\mathrm{FEV}_{1} / \mathrm{FVC}$ ratio of $67 \%$ (percentages of predicted values 90,114 , and 81 respectively ${ }^{3}$ ).

Specific inhalation challenges were carried out four days after the patient had stopped work. On two consecutive days the patient tipped lactose or penicillamine powder from one tray to another in a cubicle. ${ }^{4}$ On the day the patient tipped lactose for 15 minutes there were no appreciable fluctuations in $\mathrm{FEV}_{1}(<6 \%)$ (figure). At the end of the day his bronchial responsiveness to histamine was assessed, a Wright nebuliser

Address for reprint requests: Dr Jean-Luc Malo, Department of Chest Medicine, Hôpital du Sacré-Coeur, 5400 W, Gouin, Montreal, Canada H4J 1C5.

Accepted 3 November 1988 with an output of $0.14 \mathrm{ml} / \mathrm{mm}$ being used. ${ }^{5}$ The provocative concentration causing a $20 \%$ fall in $\mathrm{FEV}_{1}\left(\mathrm{PC}_{20}\right)$ was $2.2 \mathrm{mg} /$ $\mathrm{ml}$ (mild bronchial hyperresponsiveness). On the third day the patient tipped penicillamine for progressively increasing periods for a total of 30 minutes. He had an isolated late asthmatic reaction, seen as a fall in $\mathrm{FEV}_{1}$ (figure). The subject also sneezed during this day. At the end of the day the $\mathbf{P C}_{20}$ was $3.0 \mathrm{mg} / \mathrm{ml}$. The penicillamine specific IgE value ${ }^{6}$ in our patient $(225 \mathrm{cpm})$ was similar to the values found in four atopic controls (230 (SD 50.6) cpm) and four non-allergic control subjects $(147(12 \cdot 1) \mathrm{cpm})$.

\section{Discussion}

This report shows that penicillamine can cause occupational asthma. In our patient the challenge test produced an isolated late asthmatic reaction. Skin test responses to penicillamine were negative and the specific IgE levels were normal. Thus the mechanism of the asthmatic reaction does not seem to be IgE mediated. Antibiotics causing occupational asthma ${ }^{12}$ are low molecular weight compounds and generally cause late asthmatic reactions. The mechanism responsible for the reaction is not yet understood but may be a pharmaco-

FEV, (I)

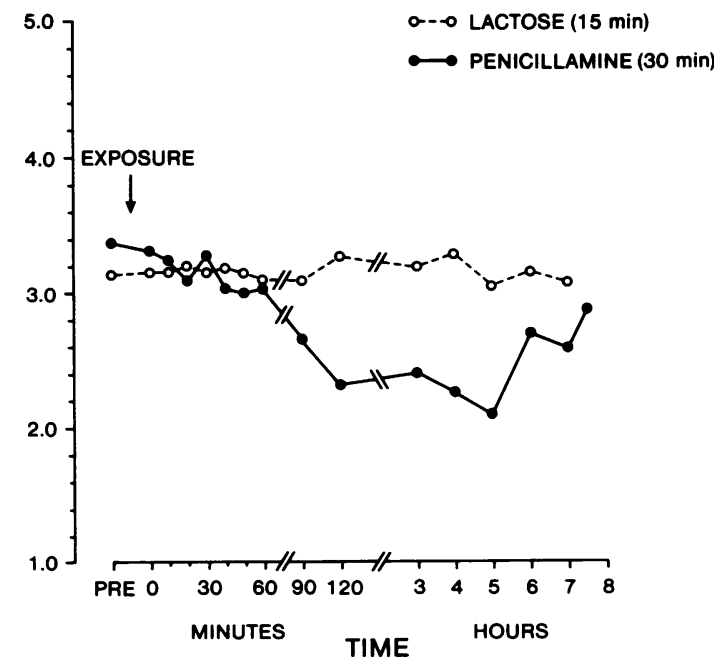

Change in $F E V_{1}$ in relation to inhalation challenges with lactose (duration $15 \mathrm{~min}$ ) and penicillamine (duration $30 \mathrm{~min}$ ). 
logically induced bronchoconstriction such as has been described with isocyanates. ${ }^{1}$ No significant change in bronchial responsiveness to histamine was seen after this late reaction. Such a change might have been missed because the assessment was performed only once. These changes are not, however, always present after late asthmatic reactions. ${ }^{78}$

We want to thank Katherine Tallman for reviewing the manuscript.

\section{References}

1 Chan-Yeung M, Lam S. Occupational asthma. Am Rev Respir Dis 1986;133:686-703.

2 Pauli G, Bessot JC, Dieteman-Molard A. Occupational asthma: investigations and etiological factors. Bull Eur Physiopathol Respir 1986;22:399-425.
3 Knudson RJ, Slatin RC, Lebowitz MD, Burrows B. Changes in normal maximal expiratory flow volumes curve with growth and aging. Am Rev Respir Dis 1983;127:725-34.

4 Pepys J, Hutchcroft BJ. Bronchial provocation tests in etiologic diagnosis and analysis of asthma. Am Rev Respir Dis 1975; 112:829-59.

5 Cockcroft DW, Killian DN, Mellon JJA, Hargreave FE. Bronchial reactivity to inhaled histamine: a method and clinical survey. Clin Allergy 1977;7:235-43.

6 Tarlo SM, Shaikh W, Bell B, et al. Papain-induced allergic reactions. Clin Allergy 1978;8:207-15.

7 Cartier A, Malo ML, Forest F, et al. Occupational asthma in snow crab-processing workers. J Allergy Clin Immunol 1984;74: 261-9.

8 Malo JL, L'Archevêque J, Cartier A. Significant changes in nonspecific bronchial responsiveness after isolated immediate bronchospastic reactions due to isocyanates but not after a late reaction caused by plicatic acid. J Allergy Clin Immunol (in press). 